\title{
Financial literacy and financial behavior with the mediating effect of family financial socialization in the financial institutions of Lahore, Pakistan
}

\author{
Sumaira Khawar and Aamir Sarwar ${ }^{*}$ (1)
}

\begin{abstract}
Purpose: The main purpose of this study was to find out the relationship between financial literacy and financial behavior and to discover the mediating influence of family financial socialization on this relationship. The study also particularizes that how personal knowledge of finance of an employee and whatever they have learned through family socialization will help them to make sound decisions having a financial impact on them and their family.

Design/methodology/approach: Employees of financial institutions employed and residing in Lahore, Pakistan, were the target population of this report. It was a cross-sectional quantitative research study. By using a detailed questionnaire, primary data were obtained. The sample size was 330; through convenience sampling, employees employed in banks were chosen. Descriptive analysis, parametric test, reliability test, and correlational examination with the aid of SPSS 23 and the use of SmartPLS 3.0. are knowledge investigation techniques used in this examination study to infer outcomes.

Results/findings: The outcomes which are created from this exploration include: (1) there was no distinction in the financial conduct of representatives from various socioeconomics gatherings. Financial education has a critical positive relationship with financial behavior. (2) Family financial socialization additionally shows a huge positive relationship with financial education and financial behavior. (3) Financial education demonstrated a remarkable abnormal impact on financial behavior through family financial socialization. (4) Family financial socialization shows partial mediation between financial literacy and financial behavior. We can accomplish that formal, as well as informal, training of finance decides the financial behavior of people.
\end{abstract}

Originality/value: This study is the first of this kind to examine the association between financial literacy, and financial behavior using family financial socialization as a mediator and employees of financial institutions as the target population.

Keywords: Financial literacy, Family financial socialization, Financial behavior, Financial institutions

*Correspondence: asarwar@gmail.com

Institute of Business and Information Technology, University of the Punjab, New Campus, Lahore, Pakistan

\section{Introduction}

These days, the growth of the global economy is shaping evolution in the financial sense [23]. It is increasingly important to make better financial decisions because of greater accessibility to new complex financial products, which is why financial literacy is needed as it affects financial choices $[16,17,25]$. The 2008 economic 
downturn also paid significant attention to financial literacy and shifted government approaches to raise awareness of the long-term financial requirements of the person. This political move expands the significance of families' capability to take financial obligations and to put something aside for their future needs [3, 22].

Workers experience and handle monetary choices, including choices identified with reserve funds and speculations. As monetary components have ended up being dynamically interesting and individuals are given new and forever refined financial terms. There is easy access to the debt than previously and chances to borrow are plenty. So, numerous employees are not prepared to make healthy financial choices [30].

If financial products are not treated with decent financial behavior, a person can effortlessly have caught in horrible monetary circumstances. A well financial behavior can be comprehended from a person's approach in dealing with the managing, planning, and controlling of finances [23].

According to Sevcík [41], literacy is a growing set of information, abilities, and methodologies that people develop during the course of life. Literacy is more than just financial knowledge it includes utilization of rational and practical abilities, attitudes, and enthusiasm. Previous studies showed that parents who permit their offspring to make financial choices and let them pick up from those decisions, those individuals have financial self-efficacy in them. Parents play an important role in shaping the financial knowledge and skills their children need to have sound financial behavior [40].

\section{Purpose of the study}

With regard to Pakistan, an insignificant study has been finished on subjects like financial behavior, financial literacy, and family financial socialization. As Pakistan is a monetarily non-industrial nation, the absence of mindfulness just as information about monetary issues among individuals is as yet the essential concern. The changes presented by the public authority of Pakistan have expanded the obligation among representatives of monetary establishments to design future monetary requirements. High occupation indecision and simple admittance to credit have an unnecessary outcome of financial behavior. Along these lines, it is fundamental to go through an investigation on this point. Along these lines, this examination stresses the connection between financial literacy and financial behavior of representatives with the mediating impact of family financial socialization in financial institutions of Lahore, Pakistan. The study focused on the financial decisions made by employees regarding managing their savings and investments and helping their families in making all such decisions.
How they use their financial knowledge and whatever they have learned through family socialization. How do they make decisions to get the financial benefits out of the financial options available to them?

\section{Research objectives}

- To discover the mediating influence of family financial socialization among financial literacy and financial behavior of employees of financial institutions.

\section{Literature Review}

\section{Financial literacy}

Financial literacy is a requisite for each person to keep away from money-related problems [3]. Financial literacy can assist employees in achieving valuable financial behavior and adapt to any encounters, particularly concerning financial problems [24]. Lusardi and Mitchell [31] stated that "Financial literacy is knowledge and understanding of financial concepts and risks, and the skills, motivation, and confidence to apply such knowledge and understanding to make effective decisions across a range of financial contexts, to improve the financial well-being of individuals and society, and to enable participation in economic life." The capability to comprehend fundamental ideas of finance and manage everyday financial exchange is vital. Therefore, a person ought to be outfitted with better financial knowledge and financial attitudes to be able to make sensible financial choices. Financial knowledge is a significant factor in financial literacy [33, 35]. People who don't have adequate financial knowledge will encounter difficulties in managing their finances [1]. Financial literacy was operationalized by using basic questions of financial knowledge related to inflation, interest calculations, risk and return, diversification, and market functioning [19, 31]. People with developed intellectual skills show a great degree of financial literacy. Cognitive capabilities have a significant relation with numerical competence as well as with financial behavior [20]. Financial knowledge is vital, but it is an inadequate driver of accountable financial behavior. Handling one's finances is not only about financial knowledge and literacy. A person moreover required self-efficacy. Self-efficacy was related to the individual's financial behavior significantly [14, 42]. Xiao and O'Neill's [46] analyses provided evidence suggesting that high school financial education may have direct impacts and spillover effects on consumer financial capability. Financial education may affect financial satisfaction, a subjective 
measure of financial well-being, through financial literacy, financial behavior, and financial capability variables [47].

\section{Financial behavior}

Financial behavior is conduct that is associated with financial implementations [3]. Financial literacy is vital for sound financial decision making. A high degree of financial literacy escort toward better financial decisions [17]. People who are not financially literate are less likely to do financial planning and investing [45]. The absence of financial knowledge and the inability to plan for the future may result in people taking a mortgage [7]. Budgeting of the finances, spending, and purchasing attitudes influences future financial decisions [42]. A saving attitude also contributes to making a financial behavior [22]. So, financial planning, preparation for the future, budgeting, investment, and saving are the indicators of financial behavior. This investigation was conducted in Pakistan and it concluded that gender, occupation, and marital status exhibited no influence on venture capitalist's investment behavior [39]. Demographic features considering gender and age do not show any dissimilarity in the financial behavior of country-side businesspersons [11].

\section{Financial literacy and financial behavior}

Financial Literacy has a significant positive influence on financial behavior ([12, 32]; Komara et al. 2017). Financial literacy, socioeconomic factors had a noteworthy influence on financial behavior [23].

Hastings [20] clarified that individuals with created scholarly abilities and the individuals who can tackle numerical computations easily show an extraordinary level of financial education. They evaluated different readings that reasoned that intellectual capacities have a huge connection with mathematical skill just as with thorough financial behavior.

According to Drever et al. [10], it is an established phenomenon that financial behaviors that individuals follow over their adulthood were the result of financial attitudes that they have learned in their childhood.

Consumers often make bad financial decisions, according to the Edmiston and Fisher [13] report, because they do not know how to make good ones, because consumers may not understand the value of planning for the future, and because they may not perceive the trouble, they may bring upon themselves. A relationship between financial education and financial awareness and financial behavior was also demonstrated in the report.

The findings of Robb and Woodyard [37] suggested that both objective and subjective financial knowledge influence financial behavior, subjective knowledge having a larger relative impact comparatively.
Mandell and Linda [29] discoveries show that the individuals who took the course of financial management didn't assess themselves to be more savings-oriented and didn't seem to have ideal financial behavior over the individuals who had not taken the course. Comparable were the discoveries of the investigation by Tang and Baker [42] which uncovered that financial information is a significant yet deficient driver of mindful financial behavior.

\section{Family financial socialization}

Family financial socialization implies endeavors that family relates make to monetarily blend. Generally, in the compositions, it is accumulated at parental difficult work in mingling their youngsters [8]. The person's socializing is by noticing their family exceptionally their folks, by taking an interest in monetary practices, and by getting guidelines from family $[2,6]$. Family communication designs indicated a relationship with financial information [19]. Guardians' conduct and attitudes have a segment in molding their kid's financial behavior [1]. Improvement in saving and monetary arranging ideally opens entryways for upgrading the financial behavior of individuals through more family financial socialization and more self-assurance [26]. Parents have a generous impact in trim the financial knowledge and monetary ability of the kids [40]. Financial literacy isn't significantly connected with guardians' inclusion [7]. Saving conduct is influenced by their folks' eagerness, and guardians' contribution in the saving of their kids [15].

Better financial decisions are industriously connected with the financial proficiency of the individuals who settled on financial decisions. Having proper monetary information would prompt great and better financial decisions [16]. Parents training their kids about cash helps the kids and next ages to know and consent to take obligation for long haul financial success. Parents' financial instruction is a multi-generational thing. Studies demonstrated that guardians who grant their posterity to settle on financial decisions and let them get from those choices, those people have monetary self-viability in them. Guardians who demonstrated great monetary conduct to their kids, their youngsters additionally will in general have sound financial behavior [40]. In the current investigation, financial literacy is an indicator variable, and a criterion variable is financial behavior. Further, the part of family monetary socialization is concentrated as an intervening variable.

Financial Socializing is the process of learning and advancing values, knowledge, norms, standards, attitudes, and behaviors that promote well-being, financial 
viability among the individuals as explained by Danes and Yang [9].

Individuals learn about behaviors in their childhood through the interaction with socialization agents such as parents, siblings, other family members, peers, religion, schools and then practice these behaviors in their adulthood years $[10,18]$.

According to Ullah and Yusheng [44], financial socialization includes the development of standards, values, norms, and attitudes, rather than just related to managing money. As described by Asad et al. [4] financial socialization has much importance in making sound financial decisions.

According to Sabri et al. [38], parents teach their children how to manage money. Most of the teaching of a child takes place almost invisibly through witnessing the money behaviors within the family (Fig. 1).

The numerous studies listed in the literature review are the basis of our conceptual framework. As far as the relationship between financial literacy and financial behavior is concerned, multiple studies have produced diverse results. Our research has therefore attempted to explore the same relationship between financial institution workers as most of them have learned financial management (formal finance education) and are exposed to financial knowledge (on-job learning) and financial family socialization (informal financial knowledge). The relationship of financial literacy and its effect on financial behavior in Pakistan will further contribute to our conceptual framework. Our study will illustrate a different viewpoint, such as the financial behavior of the participants with formal and informal financial literacy.

\section{Research hypotheses}

Hypotheses have been drawn from the variables mentioned above and the objectives of the study to find out the relationship between variables and the impact of the mediating variable. The hypotheses include the following which will help to achieve the objectives of the research:

$\mathrm{H}_{1}$ : There is a relationship between financial literacy and the financial behavior of employees in financial institutions

$\mathrm{H}_{2}$ : There is an association between financial literacy and family financial socialization of employees in

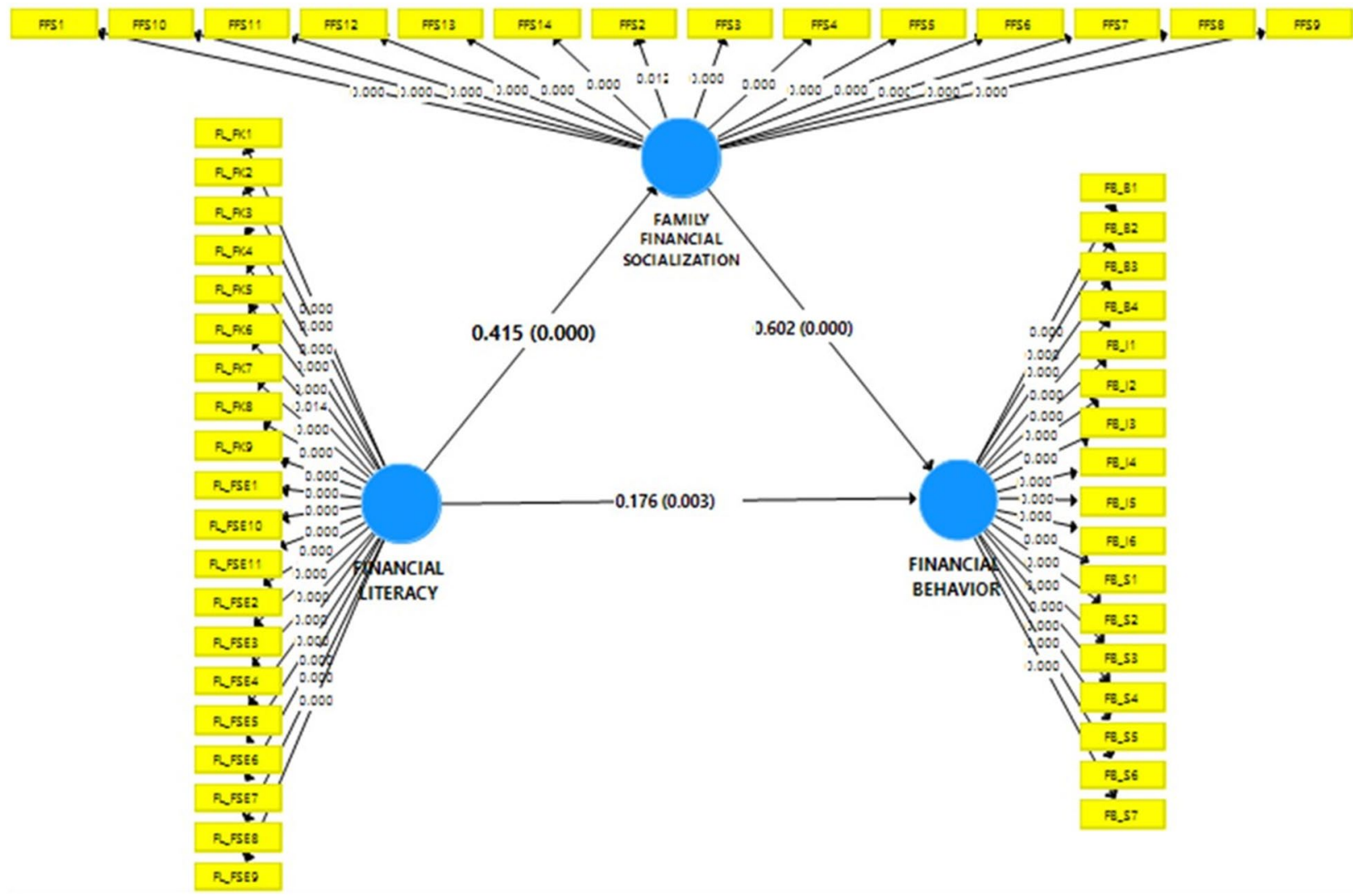

Fig. 1 Conceptual Framework of Family Financial Socialization mediating Financial Literacy and Financial Behavior 
financial institutions

$\mathrm{H}_{3}$ : There is an association between family financial socialization and the financial behavior of employees in financial institutions

$\mathrm{H}_{4}$ : There is a mediating effect of family financial socialization among financial literacy and financial behavior of employees in the financial institutions

\section{Methods}

This exploration focused on the connection between financial literacy and financial behavior of representatives of financial institutions and the mediating impact of family financial socialization on this relationship was studied. A cross-sectional examination was conducted and the kind of exploration utilized in this study was descriptive and correlational.

\section{Research design}

In order to find out the relationship between financial literacy and the financial behavior of employees, a descriptive and correlational analysis was carried out at the offices of financial institutions operating in Lahore. Financial behavior is a criterion variable in this research sample, whereas financial literacy is an independent variable, and a mediating variable is family financial socialization.

\section{Demographic variables}

- Gender

- Age

- Marital Status

- Qualification

- Institute

- Monthly Income

- Father's Education

- Father's Occupation

\section{Research Instrument}

In this research study, primary data were gathered, and for this motive, a complete questionnaire was outlined which was utilized as an instrument to assemble data from employees of financial institutions. The developed questionnaire comprises questions regarding financial literacy, financial behavior, and family financial socialization of employees in financial institutions of Lahore. There were also some questions related to the demographic information of employees included in the questionnaire.

\section{Segments of questionnaire}

The questionnaire contains two sections: (1) Demographics of employees in the financial institutions of Lahore, Pakistan. Demographic variables are adopted from [39]; (2) whereas Financial literacy, Financial Behavior (Financial Planning, Preparation for future, Budgeting, Investing, Saving), and Family financial socialization were adapted from the literature as mentioned below:

\section{Financial literacy}

The item scale used to determine financial literacy consists of 21 questions. Statements were modified and adapted from [19, 24, 25].

\section{Financial behavior}

The item scale used to measure financial behavior consists of 29 questions. Dimensions of financial behavior were adapted from $[23,24]$. Statements related to financial behavior were adapted from [34].

\section{Family financial socialization}

The item scale used to measure family financial socialization consists of 14 questions. Statements were adapted from $[18,31,43]$.

\section{Target population}

In this study, the idea of choosing employees of the financial institution as target population was based on the assumption that most of them will be having a business background, finance literate as compared to the employees working in other sectors, will be having on-job experience of finance as well. So, it will be of great interest to examine their financial behavior. Previous studies have not considered this point and mainly focused their studies on the financial behavior of students.

\section{Unit of analysis}

The unit of analysis taken in this research study was "individual" as this is related to their financial behavior.

\section{Data collection}

The respondents were contacted personally by going to each institution, and for responses, the questionnaire was given directly by hand to the respondents.

\section{Location of the study}

Data for the research were gathered from the employees working in the city of Lahore. Lahore is the secondlargest city of Pakistan in terms of population and as a business hub. All type of financial institutions has their offices in the city. 
Table 1 Reliability statistic

\begin{tabular}{lll}
\hline Scale & Cronbach's alpha & No. of items \\
\hline Financial literacy & 0.859 & 21 \\
Family financial & 0.789 & 14 \\
Socialization & & \\
Financial behavior & 0.878 & 29 \\
Over all questionnaire & 0.924 & 64
\end{tabular}

\section{Sampling technique}

A convenience sampling technique is used for this research study. Convenience sampling is a form of nonprobability sampling, where only those participants of the target population are counted in who meet definite practical criteria, for instance, ease of access and geographical vicinity is considered [5]. In the convenient sampling technique, a subset of the population that is conveniently available is used for data collection.

A sample of 330 employees was selected using convenience sampling for this research study. Primary data were collected through a questionnaire by visiting each office personally. Section "A" of the questionnaire consisted of questions related to demographics including gender, age, marital status, background, qualification, institution, monthly income, father's education, and father's occupation of employees. Section "B" of the questionnaire consisted of questions related to Financial Literacy, Financial Behavior, and Family Financial Socialization.

\section{Statistical techniques}

IBM SPSS version 23.0 was utilized for processing and analyzing the data gathered through questionnaires. Following are the statistical procedures that were implemented for the testing of hypotheses and intended for examining the various other aspects.

1. Reliability Test

2. Descriptive Test

3. Parametric Test

4. T test and ANOVA

5. Normality Test

6. Correlation Analysis

7. Mediation Analysis (Sobel test \& SmartPLS 3.0)

\section{Analysis and interpretation of data}

\section{Reliability analysis}

The total alpha value of Cronbach for financial literacy, family financial socialization, and financial behavior scale in Table 1 was 0.924 , which is greater than the alpha $=0.7$
Table 2 Descriptive statistics

\begin{tabular}{|c|c|c|c|}
\hline Demographics & Categories & Frequencies & Percentage \\
\hline \multirow[t]{2}{*}{ Gender } & Male & 229 & 69.4 \\
\hline & Female & 101 & 30.6 \\
\hline \multirow[t]{3}{*}{ Age } & $<25$ & 64 & 19.4 \\
\hline & $25-35$ & 217 & 65.8 \\
\hline & 36 and Above & 49 & 14.8 \\
\hline \multirow[t]{2}{*}{ Marital status } & Married & 172 & 52.1 \\
\hline & Single & 158 & 47.9 \\
\hline \multirow[t]{2}{*}{ Background } & Urban & 249 & 75.5 \\
\hline & Rural & 81 & 24.5 \\
\hline \multirow[t]{4}{*}{ Qualification } & $\begin{array}{l}\text { Graduation and } \\
\text { Below }\end{array}$ & 174 & 52.7 \\
\hline & Graduation & & \\
\hline & $\begin{array}{l}\text { MS/MPhil and } \\
\text { Above }\end{array}$ & 156 & 47.3 \\
\hline & Commercial Bank & 255 & 77.3 \\
\hline \multirow[t]{5}{*}{ Institution } & Leasing Company & 3 & 0.9 \\
\hline & Investment Bank & 18 & 5.5 \\
\hline & Modaraba & 12 & 3.6 \\
\hline & Other & 42 & 12.7 \\
\hline & $<$ Rs. 50,000 & 188 & 57 \\
\hline \multirow[t]{4}{*}{ Monthly income } & $\begin{array}{l}\text { Rs. } 50,000-\text { Rs. } \\
\quad 75,000\end{array}$ & 93 & 28.2 \\
\hline & $\begin{array}{l}\text { Rs. } 75,001-\text { Rs. } \\
100,000\end{array}$ & 25 & 7.6 \\
\hline & > Rs. 100,000 & 24 & 7.3 \\
\hline & Below Graduation & 124 & 37.6 \\
\hline \multirow[t]{3}{*}{ Father's Education } & Graduation & 128 & 38.8 \\
\hline & $\begin{array}{l}\text { MS/M.Phil and } \\
\text { Above }\end{array}$ & 78 & 23.6 \\
\hline & Own Business & 109 & 33 \\
\hline \multirow[t]{3}{*}{ Father's Occupation } & Private Sector & 108 & 32.7 \\
\hline & Public Sector & 83 & 25.2 \\
\hline & Landlord & 30 & 9.1 \\
\hline
\end{tabular}

benchmark, suggesting that the questionnaire is valid and has internal consistency.

\section{Descriptive statistics}

Table 2 shows the demographic features and the frequencies of the employees of financial institutions who had taken part in the research. After examining the data, it can be concluded that $69.4 \%$ of the respondents were male and $30.6 \%$ were females from the total number of 330 respondents. The majority $(85.2 \%)$ of the employees are below the age of 36 , which indicates that the majority of the employees are young or in the middle age group. A majority (52.1\%) of the employees are married and, $75.5 \%$ of the employees belong to the urban area. $52.7 \%$ of the employees have Graduation qualification and, $77.3 \%$ of 
Table 3 Parametric analysis

\begin{tabular}{lllll}
\hline Test variable & Grouping variable & P value & Test applied & Result \\
\hline Financial behavior & Gender & 0.998 & Independent $t$ test & Accepted \\
Financial behavior & Background & 0.201 & Independent $t$ test & Accepted \\
Financial behavior & Marital status & 0.322 & Independent $t$ test & Accepted \\
Financial behavior & Qualification & 0.483 & Independent $t$ test & Accepted \\
Financial behavior & Age & 0.429 & One-way ANOVA & Ane-way ANOVA \\
Financial behavior & Institution & 0.873 & One-way ANOVA & Accepted \\
Financial behavior & Monthly income & 0.095 & One-way ANOVA & Accepted \\
Financial behavior & Father's education & 0.476 & One-way ANOVA & Accepted \\
Financial behavior & Father's occupation & 0.079 & Accepted \\
\hline
\end{tabular}

Table 4 Pearson correlation between financial literacy, financial behavior and family financial socialization

\begin{tabular}{lll}
\hline Variables & Financial literacy & $\begin{array}{l}\text { Family } \\
\text { financial } \\
\text { socialization }\end{array}$ \\
\hline Financial literacy & \\
Family financial Socialization & $0.379^{* *}$ & \\
Financial behavior & $0.548^{* *}$ & $0.647^{* *}$ \\
\hline
\end{tabular}

the employees work in commercial banks. $57 \%$ of the employees have a monthly income below Rs. 50,000. The majority (38.8\%) of the employees' fathers have a graduation qualification. $33 \%$ of the employees' fathers have their own business.

\section{Hypotheses testing - parametric analysis}

Two different parametric tests for significant mean differences were applied to discover the effect of demographic variables on the financial behavior of employees in financial institutions of Lahore. Independent sample $t$ test (two-sample mean) and one-way ANOVA (multiple samples mean) were implemented, considering the level of significance at $\alpha=0.05$ [5] as shown in Table 3.

\section{Independent $\boldsymbol{t}$ test}

In Table 3, relative to financial behavior, the $\mathrm{p}$ value results for gender, background, marital status, and qualification are $0.998,0.201,0.322$, and 0.483 , respectively, which is greater than 0.05 . We therefore reject alternative hypotheses from $\mathrm{H} 1$ to $\mathrm{H} 4$ and it is concluded that given their gender, background, marital status, and qualification in financial institutions, there is no difference in the financial behavior of employees.

\section{One-way ANOVA}

The significance value in Table 3 for age, institution, monthly income, father's education, and father's occupation contrary to financial behavior are 0.429, $0.873,0.095,0.476$, and 0.079 , respectively, which shows that the $\mathrm{p}$ values are greater than 0.05 indicating we reject alternative hypotheses $\mathrm{H}_{5}$ to $\mathrm{H}_{9}$ so we concluded that there is no difference in the financial behavior of employees from a different age, institution, monthly income, father's education and father's occupation groups in financial institutions.

\section{Correlation analysis}

Financial literacy has a positive relationship with dependent variable financial behavior as it shows the value of Pearson's correlation coefficient is $r=0.548$ and significance value of $\mathrm{p}$ is 0.000 which is less than 0.01 , so we reject $\mathrm{H}_{010}$ and accept alternate hypothesis and can say that there is a positive relationship between financial literacy and financial behavior (Table 4).

Financial literacy shows a positive association with mediator family financial socialization as it shows the value of Pearson's correlation coefficient is $r=0.379$ and significance value of $\mathrm{p}$ is 0.000 which is less than 0.01 , so we reject $\mathrm{H}_{011}$ and accept $\mathrm{H}_{11}$ and can say that there is a positive association between financial literacy and family financial socialization.

Family financial socialization is also positively correlated with financial behavior as it shows the value of Pearson's correlation coefficient is $r=0.647$ and significance value of $\mathrm{p}$ is 0.000 which is less than 0.01 , so we reject $\mathrm{H}_{012}$ and accept alternate hypothesis and can say that there is a positive association between family financial socialization and financial behavior.

\section{Mediation analysis}

When the relationship between the predictor variable and criterion variable is defined using a third variable (mediator) this process is called mediation [21]. Family financial socialization is used as a mediator in our study to explain the association between financial literacy and 


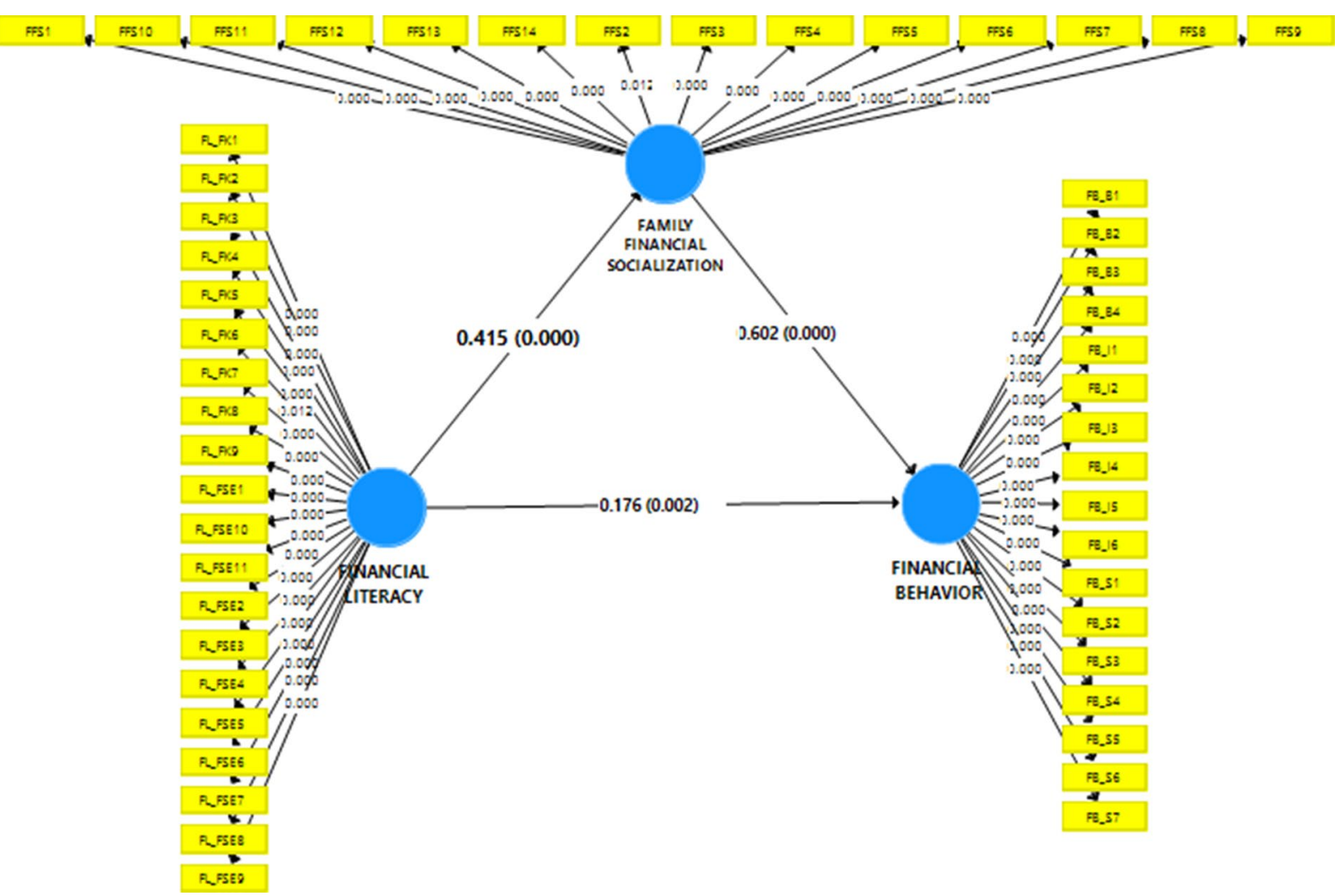

Fig. 2 Mediators Impact-Results using SmartPLS 3.0

Table 5 Relationship between variables

\begin{tabular}{|c|c|c|c|c|c|}
\hline & \multicolumn{2}{|c|}{ Family financial socialization } & \multicolumn{2}{|c|}{ Financial behavior } & \multirow{2}{*}{$\begin{array}{l}P \\
\text { value }\end{array}$} \\
\hline & Total effect & Total effect & Direct effect & Indirect effect & \\
\hline Family financial socialization & - & 0.602 & - & - & 0.000 \\
\hline Financial behavior & 0.602 & - & - & - & 0.000 \\
\hline Financial literacy & 0.415 & 0.426 & 0.250 & 0.176 & 0.000 \\
\hline
\end{tabular}

Table 6 Relation between IV, DV and mediator

\begin{tabular}{|c|c|c|c|c|c|}
\hline & $\begin{array}{l}\text { Original } \\
\text { sample (o) }\end{array}$ & Sample mean $(\mathrm{m})$ & $\begin{array}{l}\text { Standard } \\
\text { deviation (stdev) }\end{array}$ & $\begin{array}{l}T \text { statistics }(\mid \mathrm{o} / \\
\text { stdev } \mid)\end{array}$ & $P$ values \\
\hline Family financial socialization $\rightarrow$ financial behavior & 0.602 & 0.602 & 0.053 & 11.329 & 0.000 \\
\hline Financial literacy $\rightarrow$ family financial socialization & 0.415 & 0.432 & 0.061 & 6.819 & 0.000 \\
\hline Financial literacy $\rightarrow$ financial behavior & 0.176 & 0.182 & 0.06 & 2.928 & 0.004 \\
\hline $\begin{array}{l}\text { Financial literacy } \rightarrow \text { family financial } \\
\text { socialization } \rightarrow \text { financial behavior }\end{array}$ & 0.250 & 0.260 & 0.037 & 7.677 & 0.000 \\
\hline
\end{tabular}


financial behavior. For that purpose, we have used SmartPLS 3.0.

The variables and mediator used in this study are explained below:

(X) Variable $=$ Financial literacy

(Y) Variable $=$ Financial behavior

(M) Variable = Family financial socialization

Pathway a: Financial literacy predicting family financial socialization

Pathway b: Family financial socialization predicting financial behavior

Pathway c: "Total effect of financial literacy on financial behavior" before mediation.

Pathway c': "Direct effect of financial literacy on financial behavior" after mediation.

Pathway $\mathrm{a}^{*} \mathrm{~b}=$ "Indirect effect of financial literacy on financial behavior" through mediator family financial socialization (Fig. 2).

Tables 5 and 6 show the relationship between an independent variable, a dependent variable, and the mediator.

As the total effect is significant and remains significant for direct effect as well, but it shows a reduction in a beta value, this indicates the existence of a partial mediation [28].

Indirect effect, i.e., total effect minus direct effect that is $(0.426-0.250=0.176)$ as shown in Table 5 . Therefore, we accept $\mathrm{H}_{4}$ which says that there is a partial mediating effect of family financial socialization among financial literacy and financial behavior of employees in the financial institutions.

\section{Findings of the research}

The prominent outcomes of this research study are explained below:

\section{Outcomes on employees' demographics in financial institutions}

The majority of the respondents in this study were men, 2299 of whom were (69.4 percent). Of the respondents, 281 (85.2 percent) were below the age of 36 , which means that the majority of workers are young or in the middle age group. 172 of the respondents were married (52.1 percent). A very high number of respondents were from urban areas, i.e., 249 (75.5 percent). Graduates constituted 174(52.7 percent) of respondents from financial institutions. Graduation was also the qualification of the fathers of 128(38.8 percent) respondents. Most of the respondents operated in commercial banks, including traditional as well as Islamic banks, with 255 (77.3\%). Of the respondents, 188 (57 percent) have a monthly income below Rs. 50,000. Fathers of 109 (33\%) respondents were running their own business. The above-mentioned data show the complete profile of the respondents.

\section{Outcomes on financial behavior with demographics in financial institutions}

There was no difference in the financial behavior of male and female respondents. The financial behavior of the respondents of different family backgrounds and marital status, different qualifications, different age groups, employed in different types of financial institutions, different income groups, different qualifications of their fathers, and different occupations was also the same. This study is very interesting and reveals the similarities between the respondents in terms of their financial behavior from different angles.

\section{Conclusion}

This research work is mainly intended for studying the "relationship between financial literacy and financial behavior" and what influence family financial socialization brings as a mediator on this relationship. Descriptive Analysis was used to study the financial literacy, financial behavior, and family financial socialization of the employees of financial institutions. Parametric Tests were utilized to examine the means of group differences for demographics with the financial behavior of employees in financial institutions. Research outcomes show that there are no differences in the financial behavior of employees considering all demographics. This finding validates the findings of Dzomonda and Fatoki [11] according to which demographic features considering gender and age do not show any dissimilarity in the financial behavior of country-side businesspersons. Parents who showed good financial behavior to their children, their children also tend to have sound financial behavior [40]. Whereas, according to Ahmad et al. [1] parents' behavior and attitudes have a part in shaping their child's financial behavior. Results of earlier research findings coincide with the results of our research analysis using SmartPLS; the existence of indirect effect and also shows that there is a partial mediation in the relationship between financial literacy and financial behavior. Therefore, based on the results it is concluded that financial literacy is directly as well as indirectly related to the financial behavior of employees, and a rise in financial literacy brings an increase in family financial socialization which further contributes to improving the financial behavior of 
employees. Our finding also validates the findings of earlier research by Beutler \& Dickson [6], Allen [2] which concludes that individuals' socializing is by observing their family specially their parents, by participating in financial practices, and by getting instructions from family. Our research concludes that both financial literacy and family financial socialization determine the financial behavior of individuals.

\section{Limitations of the research}

This research was valuable in terms of its contribution to the financial literacy and financial behavior of employees in the financial institutions of Lahore, Pakistan. On the other hand, it would be worthy of recognizing that there were some limitations in this research which are described below:

1. The size of the sample in this examination is only restricted to the 330 employees of financial institutions which may not signify the nationwide employees of financial institutions.

2. This research study is only restricted to the employees residing in one city of Pakistan, i.e., Lahore.

3. The technique of convenience sampling is implemented in this research and therefore this technique of sampling has its constraints.

4. This research has been directed under usual conditions, and any modification in the financial institutions' circumstances has not been measured which brings a substantial impact on employees' financial behavior.

5. Many of the employees were not accessible because of their hesitancy. Some employees are not willing to participate in the research because of their hectic schedules.

\section{Recommendations of the research}

1. For further research, qualitative research techniques should be used to get an in-depth analysis of financial literacy and financial behavior.

2. This research can be conducted in different towns in Pakistan to examine the financial behavior of employees.

3. This research can be conducted in other institutions, i.e., educational institutions, manufacturing and retailing institutions, and in different software houses.

4. Factors explained in this research study for financial literacy, and financial behavior can be utilized for further analysis to get in-depth facts.
5. It has been witnessed in this research that enhancing family financial socialization improves financial behavior. Further research can be conducted for evaluating the methods of enhancing family financial socialization and its influence on financial behavior.

\section{Acknowledgements}

Not Applicable. However, we are thankful to the respondents for their time for responding to our study and helping to complete our data collection and draw the results and findings.

\section{Authors' contributions}

SK and AS conceived of the presented idea. Both developed the theory and performed the computations and verified the analytical methods. AS encouraged SK to investigate the data and supervised the findings of this work. Both authors discussed the results and contributed to the final manuscript. All authors read and approved the final manuscript.

\section{Funding}

Not applicable.

\section{Availability of data and material}

Data of the research are available with authors. Derived data supporting the findings of this study are available from the corresponding author [AS] on request.

\section{Declarations}

\section{Competing interests}

The authors declare no conflict of interest.

Received: 3 February 2020 Accepted: 1 April 2021

Published: 18 July 2021

\section{References}

1. Ahmad NW, Mawar MY, Ripain N (2016) Financial literacy of youth: a case study of islamic banking and finance students in Kolej Universiti Islam Antarabangsa Selangor. In: Proceeding of the 3rd international conference on management, pp 277-287

2. Allen MW (2008) Consumer finance and parent-child communication. In: Handbook of consumer finance research. Springer, New York, pp 351-361

3. Arianti BF (2018) The influence of financial literacy, financial behavior, and income on investment decisions. EAJ (Econ Account J) 1(1):1-10

4. Asad A, Hayat U, Kanwal A (2017) Impact of financial literacy and financial attitude on financial decisions: mediating role of financial socialization. J Manag Sci 12(3):1

5. Bell E, Bryman A, Harley B (2018) Business research methods. Oxford University Press

6. Beutler \& Dickson (2008) Consumer economic socialization. Handbook of consumer finance research 83-102:99-112

7. Calamato MP (2010) Learning financial literacy in the family. San Jose State University, California

8. Clarke MC (2005) The acquisition of family financial roles and responsibilities. Fam Consum Sci Res J 33(4):321-340

9. Danes SM, Yang Y (2014) Assessment of the use of theories within the journal of financial counseling and planning and the contribution of the family financial socialization conceptual model. J Financ Couns Plan 25:53-68

10. Drever Al, Odders-White E, Kalish CW, Else-Quest NM, Hoagland EM, Nelms EN (2015) Foundations of financial well-being: insights into the role of executive function, financial socialization, and experience-based learning in childhood and youth. J Consum Affairs 49:13-38. https://doi. org/10.1111/joca.12068 
11. Dzomonda O, Fatoki O (2018) Evaluating the effect of owners demographic characteristics on the financial management behavior of rural entrepreneurs in South Africa. Acad Account Financ Stud J

12. Edirisinghe $S$ et al (2017) Financial literacy and financial behavior of management undergraduates of Sri Lanka. Int J Manag Appl Sci

13. Edmiston K, Fisher MG (2006) Financial education at the workplace: evidence from a survey of Federal Reserve Bank employees (No. 2006-02). Federal Reserve Bank of Kansas City

14. Farrell LF (2016) The significance of financial self-efficacy in explaining women's personal finance behavior. J Econ Psychol 54:85-99

15. Firmansyah D (2014) The influence of family backgrounds toward student saving behavior: a survey of college students in Jabodetabek. Int J Sci Res Publ 4(1):1-6

16. Grohmann A, Menkhoff $L$ (2015) School, parents and financial literacy shape future financial behavior. DIW Econ Bull 5(30/31):407-412

17. Grohmann A (2018) Financial literacy and financial behavior: evidence from the emerging Asian middle class. Pac-Basin Financ J 48:129-143

18. Gudmunson CG, Danes SM (2011) Family financial socialization: theory and critical review. J Fam Econ Issues 32(4):644-667

19. Hanson TA, Olson PM (2018) Financial literacy and family communication patterns. J Behav Experim Financ 19:64-71

20. Hastings JS (2013) Financial literacy, financial education, and economic outcomes. Annu Rev Econ 5(1):347-373

21. Hayes AF et al (2011) Mediation and the estimation of indirect effects in political communication research. Sourcebook for political communication research: methods, measures, and analytical techniques 23:434-465

22. Henager R, Cude BJ (2016) Financial literacy and long-and shortterm financial behavior in different age groups. J Financ Couns Plann 27(1):3-19

23. Herawati NT et al (2018) Factors that influence financial behavior among accounting students in Bali. Int J Bus Administ 9(3):30-38

24. Ismail $S$ et al (2017) The role of financial self-efficacy scale in predicting financial behavior. Adv Sci Lett 23(5):4635-4639

25. Janor $\mathrm{H}$ et al (2017) Financial literacy and investment decisions in Malaysia and the United Kingdom: a comparative analysis. Geografia-Malays J Soc Space 12(2):

26. Jorgensen BL et al (2017) The financial behavior of emerging adults: a family financial socialization approach. J Fam Econ Issues 38(1):57-69

27. Longobardi S, Pagliuca MM, Regoli A (2017) Family background and financial literacy of Italian students: the mediating role of attitudes and motivations. Econ Bull 37(4):2585-2594

28. MacKinnon DP (2007) Mediation analysis. Annu Rev Psychol 58:593-614

29. Mandell L, Schmid Klein Linda (2009) The impact of financial literacy education on subsequent financial behavior. J Financ Counsel Plann 20(1):1

30. Mbarire TT, Ali A (2014) Determinants of financial literacy levels among employees of Kenya Ports Authority in Kenya. Res J Financ Account 5(16):44-52

31. Miller BG (2001) Early family experiences and the financial behavior of college students: the impact of gender and gambling
32. Odek J (2015) The relationship between financial literacy and individual financial behavior of employees of the hotel industry: a case study of Serena hotels (Doctoral dissertation, University of Nairobi)

33. Pavković AA (2018) Measuring the financial literacy of university students. Croat Oper Res Rev 9(1):87-97

34. Potrich ACG, Vieira KM, Kirch G (2015) Determinants of financial literacy: Analysis of the influence of socioeconomic and demographic variables. Revista Contabilidade \& Finanças 26(69):362-377

35. Potrich ACG, Vieira KM, Kirch G (2018) How well do women do when it comes to financial literacy? The proposition of an indicator and analysis of gender differences. J Behav Experiment Financ 17:28-41

36. Preacher KJ, Hayes AF (2004) SPSS and SAS procedures for estimating indirect effects in simple mediation models. Behav Res Methods Instrum Comput 36(4):717-731

37. Robb CA, Woodyard A (2011) Financial knowledge and best practice behavior. J Financ Counsel Plann 22(1):1

38. Sabri MF, Gudmunson CG, Griesdorn TS, Dean LR (2020) Influence of Family Financial Socialization on Academic Success in College. J Financ Counsel Plann 31(1):1-17

39. Sadiq MN, Ishaq HM (2014) The effect of demographic factors on the behaviour of investors during the choice of investments: evidence from Twin Cities of Pakistan. Glob J Manag Bus Res

40. Serido J, Deenanath V (2016) Financial parenting: Promoting financial self-reliance of young consumers. In: Handbook of consumer finance research. Springer, Cham, pp 291-300

41. Sevcík K (2015) Apologetika financní gramotnosti. Pedagogická orientace 25(3):465

42. Tang N, Baker A (2016) Self-esteem, financial knowledge, and financial behavior. J Econ Psychol 54:164-176

43. Thung et al (2012) Determinants of saving behavior among university students in Malaysia. Final Year Project. Kuala Lumpur: UTAR. http://eprin ts.utar.edu.my/607/1/AC-2011-0907445.pdf

44. Ullah S, Yusheng K (2020) Financial socialization, childhood experiences and financial well-being: the mediating role of locus of control. Front Psychol 11:2162

45. Van Rooij M, Lusardi A, Alessie R (2011) Financial literacy and stock market participation. J Financ Econ 101(2):449-472

46. Xiao JJ, O'Neill B (2016) Consumer financial education and financial capability. Int J Consum Stud 40(6):712-721

47. Xiao JJ, Porto N (2017) Financial education and financial satisfaction. Int J Bank Market

\section{Publisher's Note}

Springer Nature remains neutral with regard to jurisdictional claims in published maps and institutional affiliations.

\section{Submit your manuscript to a SpringerOpen ${ }^{\circ}$ journal and benefit from:}

- Convenient online submission

- Rigorous peer review

- Open access: articles freely available online

- High visibility within the field

Retaining the copyright to your article

Submit your next manuscript at springeropen.com 